\title{
Urethral prolapse- case report and photographs
}

\author{
Arun R. Mahale ${ }^{1 *}$, Anil P. Sakhare ${ }^{2}$ \\ ${ }^{1}$ Dept. of Obstetrics and Gynaecology, Borban factory area, Vazirabad, Nanded, Maharashtra, India \\ ${ }^{2}$ Department of Obstetrics and Gynecology, Shivaji Nagar, Nanded, Maharashtra, India
}

Received: 17 January 2021

Revised: 12 February 2021

Accepted: 15 February 2021

\section{*Correspondence:}

Dr. Arun R. Mahale,

E-mail: mahales@hotmail.com

Copyright: (c) the author(s), publisher and licensee Medip Academy. This is an open-access article distributed under the terms of the Creative Commons Attribution Non-Commercial License, which permits unrestricted non-commercial use, distribution, and reproduction in any medium, provided the original work is properly cited.

\section{ABSTRACT}

A report on menopausal age group urethral prolapse with illustrative photographs, its treatment and related literature review is presented.

Keywords: Urethral prolapse, Urethral prolapse photographs

\section{INTRODUCTION}

Gynaecologists are often the first to whom women approach for their urinary related problems. Amongst the many urinary problems, prolapse of urethra is one.

Urethral prolapse is an uncommon condition. ${ }^{1}$ The two age groups at which this condition is seen are premenarchal and postmenopausal. This case because of its circumferential nature appeared photogenic and hence worth forming a case report because diagnosis of this condition is considered as spot diagnosis i.e. just by inspection.

\section{CASE REPORT}

This patient a postmenopausal woman 62 years age presented with bleeding per vaginum and burning sensation in perineal region. Local (vulva) examination instantly revealed the cause. Spot diagnosis of urethral prolapse was kept (Figure 1). Other than this finding of urethral prolapse; vulva, vestibule, vagina, and cervix were normal except for the atrophic changes of menopause. Blood investigations were within normal limit. Ultrasonography revealed no abnormality in abdomen and pelvis, Pap smear of cervix was suggestive of inflammatory changes. The lesion was surgically excised by modified Kelly-Burnham technique. The modified Kelly-Burnham technique involves excising the prolapsed mucosa over an indwelling bladder catheter and closing the incision by approximating the normal mucosa to the vestibular mucosa with 3-0 polyglycolic acid interrupted absorbable sutures. The excised tissue was sent for histopathology, which revealed chronic nonspecific inflammatory lesion.

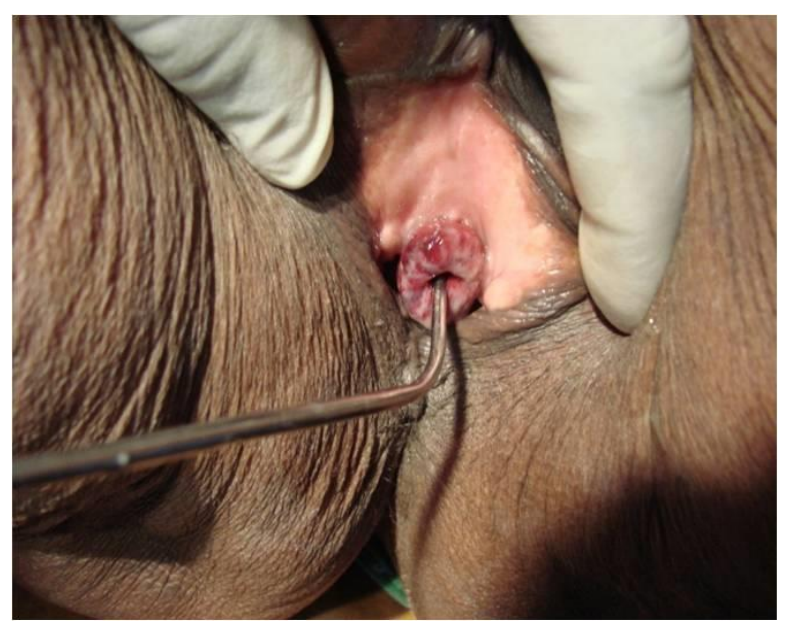

Figure 1: Photograph showing circumferential prolapsed urethra with sound in urethral opening at the centre. 
Patient was catheterized for 48 hours, and then discharged after verifying satisfactory emptying of bladder without residual urine. At follow-up visit, 15 days, vestibule looked normal (Figure 2).

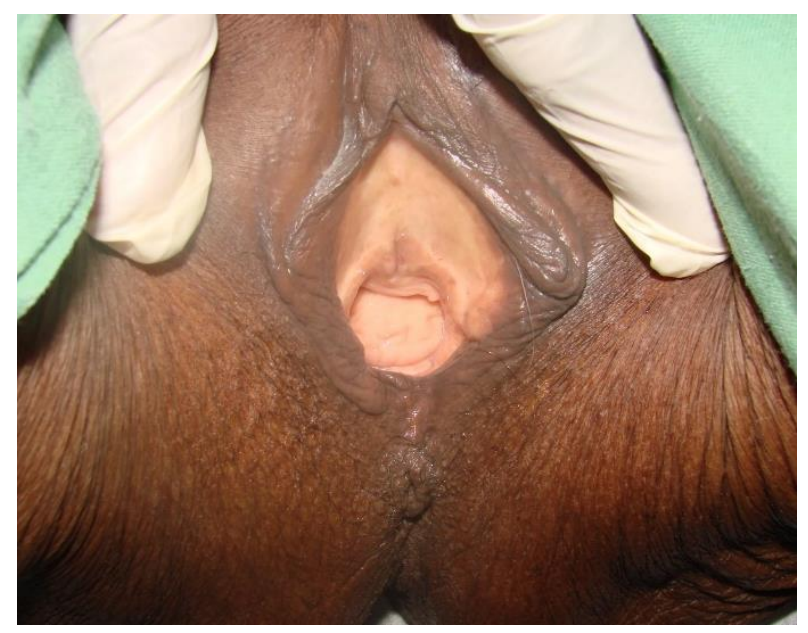

Figure 2: Photograph at post-operative follow up showing normal vulva.

\section{DISCUSSION}

Solingen first described urethral prolapse in $1732 .^{2}$ Urethral prolapse is defined as the eversion of the terminal urethra from the external meatus. It occurs at two age groups, prepubertal and postmenopausal. It is of two types, partial (usually posterior margin of urethra, with eccentric urethral meatus), and complete (circumferential prolapse with central urethra). Patient with prepubertal urethral prolapse are predominantly asymptomatic. In contrast patient with postmenopausal urethral prolapse are often symptomatic. Vaginal bleeding associated with voiding symptoms, is fairly common. $^{3}$

Urethral prolapse is diagnosed by verifying that central opening is present within the prolapsed tissue and this opening is the urethral meatus which is confirmed by recovering urine on its catheterization. ${ }^{4}$ Routine evaluation with intravenous pyelogram and voiding cystourethrogram is unnecessary except in cases in which there is doubt concerning malignancy, prolapse ectopic urethrocele or abnormalities of $\mathrm{U} \mathrm{V}$ junction. Treatment for urethral prolapse includes medical as well as surgical. Medical therapy for urethral prolapse includes local hygiene with sitz bath and topical antibiotics, steroids or estrogen creams. Medical therapy does not rapidly reduce the prolapse. Patients undergoing surgical therapy have the lowest complication rates and rapid recovery. Various surgical procedures like urethral plication, manual reduction, incision, cautery excision and suture ligatures are suggested. The preferred method of removing urethral prolapse is excision of prolapsed urethra with suturing of the incision and short-term catheterization. Post-operative complications are unusual in excision procedure but urethral stenosis, acute urinary retention recurrence of prolapse and meatal strictures are seen. Conditions that need to entertain in differential diagnosis of urethral prolapse are- Urethral caruncle, Ectopic Urethrocele, Paraurethral cyst, Rhabdomyosarcoma of the vagina. Histopathology of excised mucosa is ideal to rule out neoplastic conditions at this age, of postmenopausal phase of life.

\section{CONCLUSION}

Very illustrative photographs which would simplify spot diagnosis of urethral prolapse are reported.

Funding: No funding sources

Conflict of interest: None declared

Ethical approval: Not required

\section{REFERENCES}

1. Green J, Brodie A, Tassadaq T. A rare case of urethral prolapse in a postmenopausal woman. Case Rep. 2017;2017:2017.

2. Rackley R, Vasavada S, Ingber M. Urethra prolapse. E medicine. Available at: http://emedicine.medscape.com/article/443165-print. Accessed on 20 September 2020.

3. Klein I, Dekel Y, Stein A. Spontaneous postmenopausal urethral prolapse treated surgically and successfully. Case Rep Urol. 2014;2014: 695471.

4. Shurtleff BT, Barone JG. Urethral prolapse: four quadrant excisional technique. J Pediatr Adolesc Gynecol. 2002;15(4):209-11.

Cite this article as: Mahale AR, Sakhare AP.

Urethral prolapse- case report and photographs. Int J Reprod Contracept Obstet Gynecol 2021;10:1227-8. 